\title{
Effects of dietary fibrolytic enzymes on chewing time, ruminal fermentation, and performance of mid-lactating dairy cows
}

\author{
T.H. Silva ${ }^{a}$, C.S. Takiya ${ }^{a}$, T.H.A. Vendramini ${ }^{a}$, E. Ferreira de Jesus ${ }^{b},{ }^{b}$ F. Zanferari ${ }^{a}$, \\ F.P. Rennó ${ }^{\mathrm{a}, *}$ \\ a Department of Animal Nutrition and Production, University of Sao Paulo, Pirassununga, Brazil \\ b Department of Animal Science, UNESP-Universidade Estadual Paulista “Júlio de Mesquita Filho', Jaboticabal, Brazil
}

\section{A R T I C L E I N F O}

\section{Article history:}

Received 10 February 2016

Received in revised form 15 August 2016

Accepted 16 August 2016

\section{Keywords:}

Cellulase

Chewing activity

Fiber digestion

Neutral detergent fiber

Xylanase

\begin{abstract}
A B S T R A C T
Exogenous fibrolytic enzymes (EFE) can increase ruminal digestion of neutral detergent fiber (NDF) and improve its fermentation for cattle. Twenty-four multiparous Holstein cows ( $33.72 \pm 7.63 \mathrm{~kg}$ milk $/ \mathrm{d}$ and $176 \pm 82.27$ days in milk - DIM, at the start of the experiment) were used in a replicated $4 \times 4$ Latin square experimental design. Increasing doses of a commercial product was used to evaluate the effect of xylanase activity (100 units per gram of product) on intake and total-tract digestion of nutrients, sorting index, chewing time, milk yield and composition, $\mathrm{N}$ use, and ruminal fermentation. Treatments consisted of $0,8,16$ or $24 \mathrm{~g} / \mathrm{d}$ per cow of EFE product mixed into the concentrate. Corn silage was used as forage source. The basal diet had a forage-to- concentrate ratio of 50:50 (dry matter basis). Even though EFE supplementation had a positive linear effect on dry matter and NDF intake, it had no impact on total-tract digestion of nutrients. Moreover, this enzyme promoted a linear increase of the intake of feed with larger particle size $(>19 \mathrm{~mm})$ and quadratically affected rumination and chewing activity (hours), reaching the highest values at intermediate doses $(8 \mathrm{~g} / \mathrm{d}$ and $16 \mathrm{~g} / \mathrm{d})$. Treatments had no effect on milk yield and composition; however, the $\mathrm{N}$ use efficiency was linearly decreased by EFE, reducing thus the ability to synthesize milk and quadratically decreasing $\mathrm{N}$ retention. No treatment effect was found on ruminal $\mathrm{pH}$, whereas a negative quadratic effect on ruminal $\mathrm{NH}_{3}-\mathrm{N}$ concentration was significant. Regarding ruminal parameters, this enzyme supplementation provided linear increased in acetate, propionate, butyrate, and total short-chain fatty acids synthesis. As result, EFE supplementation improved DM and NDF intake, increasing the time spent chewing and ruminating, leading to a greater total short-chain fatty acids production in rumen. Nonetheless, EFE did not improve milk yield and composition of mid-lactating dairy cows.
\end{abstract} (c) 2016 Elsevier B.V. All rights reserved.

\footnotetext{
Abbreviations: aADF, acid detergent fiber; aNDF, neutral detergent fiber; BFCA, branched-chain fatty acids; CP, crude protein; DM, dry matter; EE, ether extract; FCM, fat corrected milk; iADF, indigestible acid detergent fiber; $\mathrm{N}$, nitrogen; $\mathrm{NH}_{3}-\mathrm{N}$, ammonia nitrogen; SD, standard error of the mean; SCFA, short-chain fatty acids.

* Corresponding author.

E-mail address: francisco.renno@usp.br (F.P. Rennó).
} 


\section{Introduction}

Ruminants are able to use nutrients from the digestion of fibrous material, and convert them into products for human nutrition (Burns, 2008). However, forage digestion is lower and slower than the digestion of other carbohydrates, limiting nutrient intake and performance of dairy cows (Yang et al., 2000; Mertens and Huhtanen, 2007). In addition, forages produced in Brazil, notably corn silages, have higher neutral detergent fiber (NDF) content and lower digestibility whether compared to those from temperate climate countries $(545 \mathrm{~g} / \mathrm{kg}$ vs. $450 \mathrm{~g} / \mathrm{kg}$, respectively; Valadares Filho et al., 2016; NRC, 2001). The relatively low digestion of forage coupled with the NDF contents of Brazilian corn silages may impair milk production efficiency, thus being necessary to explore ways to enhance fiber digestion (Varga and Kolver, 1997; Vicini et al., 2003; Allen and Piantoni, 2014).

The addition of exogenous fibrolytic enzymes (EFE) to dairy cow diets aims to increase ruminal enzyme activity and fiber digestion, to improve animal performance (Morgavi et al., 2000; Meale et al., 2014). Dehority and Tirabasso (1998) suggested that the enzyme binding sites in fiber substrates might not be fully occupied by ruminal microorganisms and, thus, the EFE supplementation could led to rise in NDF degradability. Beauchemin et al. (2003a,b) reviewed a dietary supplementation with EFE to dairy cows and observed increases in dry matter intake $(1.0 \pm 1.3 \mathrm{~kg} / \mathrm{d})$ and in milk yield $(1.1 \pm 1.5 \mathrm{~kg} / \mathrm{d})$. However, there have been reported inconsistent findings regarding the effect of such enzyme supplementation on nutrient digestion, metabolism and performance of dairy cows (Yang et al., 2000; Beauchemin et al., 2000; Reddish and Kung, 2007; Arriola et al., 2011).

Given the variability of literature findings allied to the relatively low digestibility of corn silage produced in Brazilian dairy farms, this study aimed to evaluate increasing dietary levels of EFE on intake and total-tract digestion of nutrients, sorting index, chewing time, milk yield and composition, $\mathrm{N}$ use, and ruminal fermentation in mid-lactating cows.

\section{Material and methods}

The experimental procedures were approved by the Bioethics Committee of the School of Veterinary Medicine and Animal Science, University of São Paulo (approval number: 7066120214).

\subsection{Animals, experimental design and treatments}

Twenty-four multiparous Holstein cows $(33.72 \pm 7.63 \mathrm{~kg}$ milk/d and $176 \pm 82.27$ days in milk, mean $\pm \mathrm{SD})$ were distributed into a replicated $4 \times 4$ Latin square experimental design in which two squares consisted of rumen-cannulated cows used for ruminal fermentation assessment, beyond the other parameters evaluated. The animals were housed in individual pens $\left(17.5 \mathrm{~m}^{2}\right)$, with sand bedding, feed bunks and forced ventilation. Experimental periods consisted of $21 \mathrm{~d}$, within which the first $14 \mathrm{~d}$ were for treatment adaptation and the last $7 \mathrm{~d}$ for data collection. Animals were randomized to receive $0,8,16$ or $24 \mathrm{~g} / \mathrm{d}$ per cow of Fibrozyme (Alltech, Nicholasville, KY, USA; batch: $417990-2$ ). This product is an extract from Trichoderma longibarachiatum fermentation with a minimum of $100 \mathrm{IU}$ of xylanase activity per gram of product. According to the manufacture's directions, Fibrozyme consists of a dry mixture of inactivated yeast, dry brewery yeast, yucca extract and soluble extract of Trichoderma longibarachiatum fermentation. The EFE was daily supplied in the form of a brown dry powder hand-mixed into the concentrate before morning feeding. Total Mixed Ration (TMR) was prepared twice daily and supplied to the animals in equal amounts at $0700 \mathrm{~h}$ and $1300 \mathrm{~h}$. Table 1 shows the diet composition that was formulated according to the NRC (2001) recommendations.

\subsection{Nutrient intake}

Feed offered and refusals were weighed daily to estimate feed intake and restrict orts to $50-100 \mathrm{~g} / \mathrm{kg}$ of total offered food (on as-fed basis). Throughout the sampling period, ingredients were collected during the concentrate preparation (4 samples, one per period); silage and ort samples of each cow were taken daily to provide a composite sample. Immediately after collections, samples were stored at $-20^{\circ} \mathrm{C}$ and later dried in a forced air oven at $55^{\circ} \mathrm{C}$ for $72 \mathrm{~h}$ and ground in 1 -mm or 2-mm screen Willey mill (MA340, Marconi, Piracicaba, Brazil).

Dry matter (DM, AOAC 950.15), ether extract (EE, AOAC 920.39) and total N (AOAC, 984.13) contents were analyzed in all samples according to the methods described by AOAC (2000). The contents of NDF and ADF were estimated according to the methods described by Van Soest and Mason (1991). The aNDF analysis was performed using $\alpha$-amylase without sodium sulphide (TE-149 fiber analyzer, Tecnal Equipment for Laboratory Inc., Piracicaba, Brazil). Total digestible nutrient was calculated according to NRC (2001): $\operatorname{TDN}_{1 \mathrm{X}}=\operatorname{tdNFC}+\mathrm{tdCP}+(\operatorname{tdEE} \times 2.25)+\operatorname{tdNDF}-7$, wherein tdNFC is the total digestible non-fiber carbohydrate, tdCP is the total digestible crude protein, tdEE is the total digestible EE, and tdNDF is the total digestible NDF. Non-fiber carbohydrate was calculated according to Hall (2000) in which: NFC $=100-(\mathrm{CP}+\mathrm{NDF}+\mathrm{EE}+\mathrm{ash})$ and net energy of lactation (NEL) was calculated according to Weiss et al. (1992): NEL (Mcal $/ \mathrm{kg})=0.0245 \times \mathrm{TDN}(\%)-0.12$, using 1 as processing factor. 
Table 1

Ingredients and chemical composition of basal diet ( $\mathrm{g} / \mathrm{kg} \mathrm{DM}$, otherwise stated).

\begin{tabular}{|c|c|}
\hline Item & Diet \\
\hline \multicolumn{2}{|l|}{ Ingredient } \\
\hline Corn silage & 500 \\
\hline Ground corn & 278 \\
\hline Soybean meal & 144 \\
\hline Whole raw soybean & 51.5 \\
\hline Urea & 1.30 \\
\hline Ammonium sulfate & 1.30 \\
\hline Limestone & 7.40 \\
\hline Mineral and vitamins ${ }^{a}$ & 16.2 \\
\hline Salt & 0.40 \\
\hline \multicolumn{2}{|l|}{ Chemical composition } \\
\hline Dry matter & 617 \\
\hline Organic matter & 935 \\
\hline Crude protein & 164 \\
\hline $\mathrm{PIDN}^{\mathrm{b}}$ & 15.3 \\
\hline PIDA $^{\mathrm{c}}$ & 8.90 \\
\hline Ether extract & 46.5 \\
\hline Non fiber carbohydrate $^{\mathrm{d}}$ & 416 \\
\hline Neutral detergent fiber (aNDF) & 311 \\
\hline $\mathrm{FDN}_{\mathrm{cp}}{ }^{\mathrm{e}}$ & 286 \\
\hline Acid detergent fiber & 163 \\
\hline $\mathrm{iADF}^{\mathrm{f}}$ & 45.1 \\
\hline Lignin & 40.0 \\
\hline Total digestible nutrients ${ }^{g}$ & 717 \\
\hline Net energy of lactation (MJ/ kg DM $)^{7}$ & 6.69 \\
\hline \multicolumn{2}{|l|}{ Particle size separation } \\
\hline First (top) sieve (19-mm) & 71.1 \\
\hline Second sieve (8-mm) & 441 \\
\hline Third sieve $(1.18-\mathrm{mm})$ & 147 \\
\hline Collection pan & 341 \\
\hline
\end{tabular}

a Contained per kg: Ca, 88 g/kg; P, 42 g/kg; S, 18 g/kg; Mg, 45 g/kg; K, 20 g/kg; Na, 123 g/kg; Co, 14 mg/kg; Cu, 500 mg/kg; Cr, 20 mg/kg; Fe, 1050 mg/kg; I, 28 mg/kg; Mn, 1400 mg/kg; Se, 18 mg/kg; Zn, 2800 mg/kg; F, 420 mg/kg; Biotin, 80 mg/kg; vitamin A, 200,000 IU/kg; vitamin D3, 40,000 IU/kg; and vitamin $\mathrm{E}, 1200 \mathrm{IU} / \mathrm{kg}$.

b Insoluble crude protein of neutral detergent fiber content.

${ }^{\mathrm{c}}$ Insoluble crude protein of acid detergent fiber content.

d According to NRC (2001): NFC $=100-(\mathrm{CP}+\mathrm{NDF}+$ Ether Extract + ash $)$.

e Neutral detergent fiber corrected to crude protein content.

${ }^{\mathrm{f}}$ Indigestible acid detergent fiber.

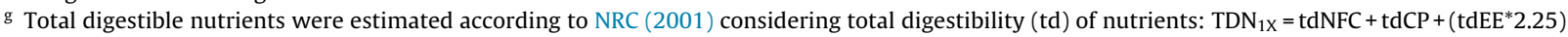
+ tdNDF -7 , and net energy of lactation $\left(\mathrm{NE}_{\mathrm{L}}\right)$ was calculated according to Weiss et al. (1992): $\mathrm{NE}_{\mathrm{L}}(\mathrm{Mcal} / \mathrm{kg})=0.0245 \times \mathrm{TDN}(\%)-0.12$, using 1 as processing factor.

\subsection{Total-tract digestion}

Fecal samples were collected from each cow every $9 \mathrm{~h}$ from day 16 until day 18 , in each experimental period, representing every $3 \mathrm{~h}$ of a $24 \mathrm{~h}$ period. After collections, samples were stored at $-20^{\circ} \mathrm{C}$, and afterwards proportionally homogenized (on wet-basis) to form composite samples, which were then dried in a forced air oven at $55^{\circ} \mathrm{C}$ during $72 \mathrm{~h}$. The dried samples of feed ingredients, orts and feces were ground in a 2-mm screen Willey mill (MA340, Marconi, Piracicaba-Brazil). Total DM fecal excretion was determined based on indigestible ADF (iADF) intake and iADF concentration in feces according to Casali et al. (2008). For analysis of iADF content, dried and ground samples of feed, orts, and feces were placed in bags of non-woven fabric tissue (pore size $50 \mu \mathrm{m}, 100 \mathrm{~g} / \mathrm{m}^{2}$ ) with dimensions of $5 \times 5 \mathrm{~cm}$. Samples were incubated in the rumen of two cannulated dry cows receiving a similar diet of the current experiment. After $288 \mathrm{~h}$ incubation, samples were washed in running tap water, and analyzed for ADF, as previously described.

\subsection{Sorting index}

Total mixed ration and refusals were analyzed for particle size distribution using a particle separator system (Penn State Particle Separator-Nasco, Fort Atkinson, WI, USA) as described by Kononoff and Buckmaster (2003), to determine the extent of sorting (Silveira et al., 2007). This equipment is able to detect four particle fractions $(>19.0,>8.0,>1.18$ and $<1.18 \mathrm{~mm}$ ).

The sorting index was calculated as the ratio of actual intake to expected intake for each particle size (as-fed basis), according to Eqs. (1)-(3):

(1) Expected intake = particle size distribution of the TMR (\%, as fed basis $) \times$ actual as-fed intake; 
(2) Actual intake $=(\%$ particle size distribution in the TMR $\times$ amount of feed offered $)(\%$, as-fed basis $)-(\%$ particle size distribution in the orts samples $\times$ amount feed refused) (\%, as-fed basis);

(3) Sorting Index = (actual intake/expected intake) (\%, as-fed basis), which: $1=$ no sorting; $<1$ sorting against, and $>1$ indicates sorting for, particles on the particular screen (Silveira et al., 2007).

\subsection{Time spent eating, chewing and ruminating}

Feeding behavior data were recorded on days 14,15 and 16 of each experimental period. Animals were observed for $72 \mathrm{~h}$ with visual observations made each 5-min intervals. Ruminating, feeding and chewing measurements (hours and hours $/ \mathrm{kg}$ NDF) were carried out to ascertain if there was influence of treatments on masticatory activity. These data were used to calculate the time spent chewing per kg dietary dry matter and unit NDF intake (Armentano and Pereira, 1997).

\subsection{Milk yield and composition}

Cows were mechanically milked twice daily $(0600 \mathrm{~h}$ and $1600 \mathrm{~h})$ and milk yield was electronically recorded (Alpro ${ }^{\circledR}$, DeLaval, Tumba, Sweden). Milk samples were likewise collected from each cow (according to the individual milk yield in each milking) on days 15-17 of each experimental period. Immediately after collections, milk samples were analyzed for fat, protein and lactose contents by infrared analysis (Lactoscan ${ }^{\circledR}$, Entelbra, Londrina, Brazil). Sub-samples (20 mL) were deproteinized, according to Broderick and Clayton (1997), and analyzed for milk urea nitrogen using commercial kits (Bioclin ${ }^{\circledR}$, Belo Horizonte, Brazil) by an enzymatic colorimetric endpoint method, and reading was performed by a semi-automatic biochemistry analyzer (SBA-200, CELM ${ }^{\circledR}$, São Caetano do Sul, Brazil). Fat-corrected milk (FCM) was calculated according to Sklan et al. (1992) wherein: FCM $(\mathrm{kg} / \mathrm{d})=(0.432+0.1625 \times$ Fat\% $) \times \mathrm{kg}$ milk. Body weights were measured using an electronic livestock scale for large animals, after milking and before the morning feeding on days 7 and 21 of each experimental period.

\subsection{Nitrogen balance}

Nitrogen balance was calculated as the difference between $\mathrm{N}$ intake and the sum of fecal, urinary and milk $\mathrm{N}$ losses. Nitrogen excreted in milk was calculated based on milk CP concentration, milk yield, and using 6.38 as conversion factor. Nitrogen excreted in feces was estimated based on the following equation: fecal $\mathrm{N}=\mathrm{CP}$ in feces $(\mathrm{g} / \mathrm{kg}) \times \mathrm{DM}$ fecal excretion $(\mathrm{kg} / \mathrm{d}) \div 6.25$. To determine the total $\mathrm{N}$ excretion, urine samples were collected every $9 \mathrm{~h}$ from day 16 until day 18 of each experimental period, representing every $3 \mathrm{~h}$ of $24 \mathrm{~h}$ period. Each urine sample was filtered and an aliquot $(20 \mathrm{~mL})$ was immediately diluted with a sulfuric acid solution $(80 \mathrm{~mL}, 0.036 \mathrm{~N})$, being stored at $-20^{\circ} \mathrm{C}$. Daily total urine output was estimated based on urinary creatinine concentration (Chizzotti et al., 2008), which was determined using commercial kits (Bioclin ${ }^{\circledR}$ ) by kinetic colorimetric enzymatic reaction with readings taken in a semi-automatic biochemistry analyzer (SBA- 200, CELM ${ }^{\circledR}$ ). Therefore, total urine volume was estimated dividing daily urinary creatinine excretion by creatinine concentrations in composite urine samples. Urinary daily excretion of creatinine was estimated based on the ratio of $24.05 \mathrm{mg} / \mathrm{kg}$ of animal body weight, as described by Chizzotti et al. (2008). Finally, total $\mathrm{N}$ in urine samples was determined according to the methods described by AOAC (method 984.13, AOAC, 2000).

\subsection{Ruminal fermentation}

Ruminal fluid was collected from multiple sites (anterior dorsal, anterior ventral, medium ventral, posterior dorsal, and posterior ventral) within the rumen of cannulated cows, before morning feeding (time 0 ) and 2, 4, 6, 8, 10, 12, 14 and $16 \mathrm{~h}$ thereafter. The next step was measuring pH with a potentiometer (MB-10, Marte, Santa Rita do Sapucaí, Brazil). Then, aliquots $(1600 \mu \mathrm{L})$ of ruminal fluid were mixed with methanoic acid $\left(400 \mu \mathrm{L}\right.$, p.a. $\left.\mathrm{H}_{2} \mathrm{CO}_{2}\right)$, being centrifuged at $7000 \times \mathrm{g}$ for 15 min at $4{ }^{\circ} \mathrm{C}$, and the supernatant of each sample was stored at $-20^{\circ} \mathrm{C}$ for further short chain fatty acids (SCFA) analyses. In addition, other aliquots $(2 \mathrm{~mL})$ of ruminal fluid were mixed to sulfuric acid solution $\left(1 \mathrm{~mL}, 0.5 \mathrm{Mol} / \mathrm{L} \mathrm{H}_{2} \mathrm{SO}_{4}\right)$ and stored at $-20^{\circ} \mathrm{C}$ for subsequent analysis of ammonia nitrogen $\left(\mathrm{NH}_{3}-\mathrm{N}\right)$ by the colorimetric phenol-hypochlorite method (Broderick and Kang, 1980).

Ruminal SCFA were measured using a gas chromatograph (GC-2014, Shimadzu, Tokyo, Japan) equipped with a capillary column (Stabilwax, Restek, Bellefonte, USA). The gases used were helium as the carrier gas $(8.01 \mathrm{~mL} / \mathrm{min}$ flow), hydrogen as the fuel gas (pressure of $60 \mathrm{kPa}$ ), and synthetic air as oxidizer gas (pressure of $40 \mathrm{kPa}$ ). Steamer temperature was set at $220^{\circ} \mathrm{C}$; ionization detector flames at $250^{\circ} \mathrm{C}$; and separation column at $145^{\circ} \mathrm{C}$ for $3 \mathrm{~min}$, which was then raised to $10^{\circ} \mathrm{C} / \mathrm{min}$ until reaching $200^{\circ} \mathrm{C}$. Short chain fatty acids concentrations were corrected for the amount of liquid and solid mass in the rumen by equation proposed by Hall et al. (2015): SCFA $(\mathrm{mol})=$ SCFA $(\mathrm{mmol} / \mathrm{L}) \times$ Volume ruminal liquid $(\mathrm{L}) \times 1(\mathrm{~mol}) / 1000$ (mmol). Ruminal contents were evacuated manually through the ruminal cannula at $0400 \mathrm{~h}$ ( $4 \mathrm{~h}$ before the morning feeding) on day 20 and at $1200 \mathrm{~h}$ ( $4 \mathrm{~h}$ after the morning feeding) on d 21 of each period, withdrawing aliquots ( $10 \%$ of total evacuated, on wet-basis). Total ruminal content mass and volume were determined and the sampled aliquots were squeezed through a nylon screen (pore size: $1 \mathrm{~mm}$ ) for separation into primarily solid and liquid phases, weighing both to minimize sampling errors. Moreover, dry matter was determined by drying at $55^{\circ} \mathrm{C}$ for more than $72 \mathrm{~h}$ in a forced-air oven. Thus, ruminal pool 
Table 2

Effects of increasing doses of exogenous fibrolytic enzymes on nutrient intake and total tract digestion and sorting index of mid-lactating dairy cows.

\begin{tabular}{|c|c|c|c|c|c|c|c|}
\hline \multirow[t]{2}{*}{ Item } & \multicolumn{4}{|c|}{ Treatment $^{\mathrm{a}}$} & \multirow[t]{2}{*}{ SEM } & \multicolumn{2}{|l|}{$P$-value } \\
\hline & 0 & 8 & 16 & 24 & & Linear & Quadratic \\
\hline \multicolumn{8}{|l|}{ Intake (kg/d) } \\
\hline Dry matter & 23.1 & 23.7 & 23.3 & 23.8 & 0.370 & 0.047 & 0.864 \\
\hline Total digestible nutrient & 16.7 & 16.9 & 16.8 & 17.1 & 0.261 & 0.077 & 0.588 \\
\hline Non-fiber carbohydrate & 9.91 & 9.97 & 9.93 & 10.1 & 0.153 & 0.237 & 0.590 \\
\hline Neutral detergent fiber & 6.66 & 6.82 & 6.73 & 6.97 & 0.119 & 0.048 & 0.652 \\
\hline Crude protein & 3.95 & 4.02 & 3.97 & 4.03 & 0.061 & 0.297 & 0.977 \\
\hline Ether extract & 1.07 & 1.09 & 1.09 & 1.09 & 0.017 & 0.157 & 0.512 \\
\hline \multicolumn{8}{|l|}{ Total tract digestion $(\mathrm{g} / \mathrm{kg})$} \\
\hline Dry matter & 744 & 736 & 742 & 741 & 0.640 & 0.948 & 0.705 \\
\hline Neutral detergent fiber & 470 & 473 & 491 & 472 & 1.129 & 0.801 & 0.571 \\
\hline Crude protein & 760 & 744 & 758 & 758 & 0.691 & 0.856 & 0.379 \\
\hline Ether extract & 734 & 716 & 733 & 720 & 1.199 & 0.637 & 0.794 \\
\hline \multicolumn{8}{|l|}{ Sorting index ${ }^{b}$} \\
\hline $19 \mathrm{~mm}$ & 0.701 & 0.743 & 0.781 & 0.840 & 0.023 & 0.001 & 0.722 \\
\hline $19-8 \mathrm{~mm}$ & 1.01 & 1.00 & 1.00 & 1.01 & 0.003 & 0.829 & 0.043 \\
\hline $8-1.18 \mathrm{~mm}$ & 1.02 & 1.02 & 1.02 & 1.02 & 0.002 & 0.702 & 0.101 \\
\hline$<1.18 \mathrm{~mm}$ & 1.03 & 1.03 & 1.05 & 1.04 & 0.005 & 0.131 & 0.531 \\
\hline
\end{tabular}

a Dietary addition of $0,8,16$, and $24 \mathrm{~g} / \mathrm{cow}$ per day of exogenous fibrolytic enzymes.

b According to Silveira et al. (2007).

size (kg) of DM was determined by multiplying total mass of ruminal digesta by the DM of each sample (Oba and Allen, 2003). And finally, ruminal liquid volume was determined by subtracting DM from total ruminal digesta.

\subsection{Statistical analysis}

The obtained data were submitted to simple polynomial regression using SAS Proc Mixed SAS, version 9.4 (Statistical Analysis for Windows - Institute Inc., Cary, USA) according to the following model:

$$
\mathrm{y}_{i j k l}=\mu+\alpha_{i}+\beta_{j}+\mathrm{y}_{l}+\mathrm{cy}_{k l}+\mathrm{e}_{i j k}
$$

wherein: $\mathrm{y}_{i j k l}$ stands for the observation of animal $k$ in treatment $i$ at period $j$ in squared $l$; $\alpha_{i}$ represents the fixed effect of the $i$ th treatment $(i=1-4) ; \beta_{j}$ is the fixed effect of the $j$ th period $(j=1-4) ; \gamma_{l}=$ is the fixed effect of the $l$ th square $(l=1-6)$; $c_{k l}$ represents the random effect of animal within square $(k=1-24)$; and $\mathrm{e}_{i j k}$ the random error associated with each observation. Means were adjusted by the LSMEANS procedure, and degrees of freedom were calculated using the method detailed by Kenward and Roger (1997).

Ruminal fermentation variables $(0,2,4,6,8,10,12,14$ and $16 \mathrm{~h}$ after morning feeding) were analyzed as repeated measures, ordered by time, using the PROC MIXED procedure of SAS 9.4, and considering the following statistical model:

$$
\mathrm{y}_{i j k l}=\mu+\alpha_{i}+\beta_{j}+\mathrm{y}_{l}+\mathrm{cy}_{k l}+\mathrm{e}(\mathrm{a})_{i j k l}+\delta_{m}+\alpha \delta_{i m}+\mathrm{e}(\mathrm{b})_{\mathrm{ijklm}}
$$

wherein: $\mathrm{y}_{i j k l}$ represents the observation for animal $k$ in a given treatment $i$ at a period $j$ in squared $l$; $\alpha_{i}$ stands for the fixed effect of the $i$ th treatment $(i=1-4) ; \beta_{j}$ represents the fixed effect of the $j$ th period $(j=1-4)$; $\gamma_{l}$ expresses the fixed effect of the lth square $(l=1-6) ; c_{k l}$ is the random effect of the animal within square $(k=1-24)$; $\mathrm{e}_{i j k}$ depicts the random error associated with each observation of main plot (a); $\delta_{m}$ represents the fixed effect of the $m$ th time $(m=0,2,4,6,8,10,12,14$ and 16$) ; \alpha \delta_{\text {im }}$ plays the fixed effect of interaction between $i$ treatment and $m$ time; and $\mathrm{e}(\mathrm{b})_{i j k l m}$ stands for the random error associated with each observation of subplot (b). Covariance matrix was estimated using the lowest value found by Akaike's criterion. Moreover, linear and quadratic contrasts were performed to evaluate the dose-response effect of EFE addition. Significance level was set at $5 \%(P \leq 0.05)$ and tendency towards significance at $0.05<P<0.10$.

\section{Results}

The use of EFEs promoted linear increases $(P \leq 0.048)$ of DM and NDF intake and tended to increase linearly $(P=0.077)$ TDN intake (Table 2). However, EFE did not significant effect $(P \geq 0.379)$ on total-tract digestion of nutrients of dairy cows. Additionally, EFE supplementation provided a linear increase $(P=0.001)$ in the intake of feed with particle sizes $>19$ mm, besides a quadratic effect $(P=0.043)$ for intake of particles sizes $19-8 \mathrm{~mm}$ particle size. Overall, treatments quadratically affected ruminating $(P=0.005)$ and chewing activity $(P=0.002)$ of animals (Table 3$)$.

Milk yield and composition were similar among the treatments (Table 4). Nonetheless, enzymatic supplementation tended to have a quadratic effect on milk CP concentration $(P=0.074)$ and a linear effect increasing body weight gain $(P=0.012)$ of cows. Exogenous fibrolytics enzyme supply caused also a linear reduction of the efficiency of $\mathrm{N}$ use for milk 
Table 3

Effects of increasing doses of exogenous fibrolytic enzymes on time eating, ruminating and chewing of mid-lactating dairy cows.

\begin{tabular}{|c|c|c|c|c|c|c|c|}
\hline \multirow[t]{2}{*}{ Item } & \multicolumn{4}{|c|}{ Treatment $^{\mathrm{a}}$} & \multirow[t]{2}{*}{ SEM } & \multicolumn{2}{|l|}{$P$-value } \\
\hline & 0 & 8 & 16 & 24 & & Linear & Quadratic \\
\hline \multicolumn{8}{|l|}{ Activities (h/kg DM) } \\
\hline Eating & 4.54 & 4.92 & 4.92 & 4.89 & 0.079 & 0.111 & 0.157 \\
\hline Ruminating & 7.64 & 8.55 & 8.46 & 8.33 & 0.095 & 0.015 & 0.005 \\
\hline Chewing & 12.2 & 13.6 & 13.4 & 13.2 & 0.095 & 0.006 & 0.002 \\
\hline \multicolumn{8}{|c|}{ Activities (h/kg NDF ${ }^{\mathrm{b}}$ ) } \\
\hline Eating time & 0.640 & 0.661 & 0.671 & 0.652 & 0.013 & 0.554 & 0.349 \\
\hline Ruminating time & 1.08 & 1.13 & 1.16 & 1.13 & 0.021 & 0.245 & 0.250 \\
\hline Chewing time & 1.70 & 1.78 & 1.79 & 1.79 & 0.032 & 0.100 & 0.250 \\
\hline
\end{tabular}

a Dietary addition of $0,8,16$, and $24 \mathrm{~g} / \mathrm{cow}$ per day of exogenous fibrolytic enzymes.

b $\mathrm{NDF}=$ neutral detergent fiber.

Table 4

Effects of increasing doses of exogenous fibrolytic enzymes on milk yield and composition of mid-lactating dairy cows.

\begin{tabular}{|c|c|c|c|c|c|c|c|}
\hline \multirow[t]{2}{*}{ Item } & \multicolumn{4}{|c|}{ Treatment $^{\mathrm{a}}$} & \multirow[t]{2}{*}{ SEM } & \multicolumn{2}{|l|}{$P$-value } \\
\hline & 0 & 8 & 16 & 24 & & Linear & Quadratic \\
\hline \multicolumn{8}{|l|}{ Yield (kg/d) } \\
\hline Milk & 31.2 & 30.9 & 31.2 & 30.8 & 0.781 & 0.590 & 0.749 \\
\hline $\mathrm{FCM}^{\mathrm{b}}$ & 31.7 & 32.2 & 31.9 & 31.6 & 0.800 & 0.743 & 0.451 \\
\hline Fat & 1.10 & 1.14 & 1.11 & 1.10 & 0.032 & 0.640 & 0.250 \\
\hline Crude protein & 0.934 & 0.933 & 0.942 & 0.921 & 0.028 & 0.537 & 0.456 \\
\hline Lactose & 1.40 & 1.40 & 1.41 & 1.38 & 0.042 & 0.570 & 0.463 \\
\hline \multicolumn{8}{|l|}{ Composition } \\
\hline Fat $(\mathrm{g} / \mathrm{kg})$ & 36.9 & 38.4 & 37.4 & 37.0 & 0.056 & 0.762 & 0.156 \\
\hline Crude protein $(\mathrm{g} / \mathrm{kg})$ & 30.9 & 31.0 & 30.9 & 30.8 & 0.010 & 0.114 & 0.074 \\
\hline Lactose $(\mathrm{g} / \mathrm{kg})$ & 46.3 & 46.5 & 46.3 & 46.2 & 0.015 & 0.327 & 0.196 \\
\hline Milk urea nitrogen (mg/dL) & 12.6 & 12.9 & 12.7 & 12.7 & 0.269 & 0.822 & 0.478 \\
\hline Body weight gain $(\mathrm{kg} / \mathrm{d})$ & 0.08 & 0.17 & 0.41 & 0.42 & 0.076 & 0.012 & 0.531 \\
\hline
\end{tabular}

a Dietary addition of $0,8,16$, and $24 \mathrm{~g} / \mathrm{cow}$ per day of exogenous fibrolytic enzymes.

b $3.5 \%$ Fat corrected milk, FCM $=(0.432+0.165 \times$ percentage of fat $) \mathrm{x}$ kg of milk, from Sklan et al. (1992).

Table 5

Effects of increasing doses of exogenous fibrolytic enzymes on nitrogen utilization of mid-lactating dairy cows.

\begin{tabular}{|c|c|c|c|c|c|c|c|}
\hline \multirow[t]{2}{*}{ Item } & \multicolumn{4}{|c|}{ Treatment $^{\mathrm{a}}$} & \multirow[t]{2}{*}{ SEM } & \multicolumn{2}{|l|}{$P$-value } \\
\hline & 0 & 8 & 16 & 24 & & Linear & Quadratic \\
\hline $\mathrm{N}$ intake $(\mathrm{g} / \mathrm{d})$ & 628 & 644 & 644 & 643 & 9.89 & 0.179 & 0.251 \\
\hline $\mathrm{N}$ fecal excretion $(\mathrm{g} / \mathrm{d})$ & 153 & 166 & 158 & 157 & 5.55 & 0.886 & 0.302 \\
\hline $\mathrm{N}$ urinary excretion $(\mathrm{g} / \mathrm{d})$ & 298 & 239 & 261 & 289 & 12.35 & 0.934 & 0.017 \\
\hline N milk secretion (g/d) & 146 & 146 & 147 & 144 & 4.40 & 0.548 & 0.431 \\
\hline $\mathrm{N}$ retention $(\mathrm{g} / \mathrm{d})$ & 36.4 & 92.3 & 95.8 & 59.4 & 11.13 & 0.360 & 0.011 \\
\hline Milk N (g/100 g N intake) & 23.2 & 22.8 & 22.7 & 22.4 & 0.60 & 0.048 & 0.756 \\
\hline
\end{tabular}

a Dietary addition of $0,8,16$, and $24 \mathrm{~g} / \mathrm{cow}$ per day of exogenous fibrolytic enzymes.

production $(P=0.048)$. Furthermore, EFE supplementation exerted a quadratic effect on urinary excretion $(P=0.017)$ and retention ( $P=0.011$, Table 5$)$ of $\mathrm{N}$ in cows. Moreover, EFE doses showed a quadratic behavior $(P=0.024)$ regarding ruminal $\mathrm{NH}_{3}-\mathrm{N}$ concentration. In contrast, concentrations of acetate $(P<0.001)$, propionate $(P=0.036)$, butyrate $(P=0.004)$, valerate $(P=0,017)$, and total SCFA $(P=0.001)$ were linearly by EFE supply. As well, the acetate-to-propionate ratio $(P=0.054)$, the proportion of propionate $(P=0.012)$ and butyrate $(P=0.046)$ in rumen were quadratically decreased by EFE supply doses. Finally, no interaction effects were found for ruminal fluid parameters (Table 6).

\section{Discussion}

We hypothesized that EFE supplementation would improve fiber digestion, ruminal fermentation, and increase milk yield. Although we found increasing DM and NDF intake, which raised ruminal production of SCFA, milk yield and composition was not altered. In view of this, Beauchemin et al. (2003a) reported potential increases in feed voluntary intake due to improvements on ruminal fiber digestion, increasing feed passage rate through the digestive tract, by EFE supplementation. In a review of twenty papers by Beauchemin et al. (2003a), EFE supplementing showed to increase in $1.0 \mathrm{~kg} / \mathrm{d}$ the DM intake of dairy cows. In the current experiment, we associated such DM intake growth (up to $0.7 \mathrm{~kg} / \mathrm{d}$ ) with rumination since it is essential to break down feed particles enabling passage though reticulo-omasal orifice (Welch, 1982). 
Table 6

Effects of increasing doses of exogenous fibrolytic enzymes on ruminal fermentation of mid-lactating dairy cows.

\begin{tabular}{|c|c|c|c|c|c|c|c|c|}
\hline \multirow[t]{2}{*}{ Item } & \multicolumn{4}{|c|}{ Treatment $^{\mathrm{a}}$} & \multirow[t]{2}{*}{ SEM } & \multicolumn{3}{|c|}{ P-value ${ }^{b}$} \\
\hline & 0 & 8 & 16 & 24 & & Time & Linear & Quadratic \\
\hline $\mathrm{pH}$ & 6.11 & 6.09 & 6.06 & 6.11 & 0.022 & $<0.001$ & 0.890 & 0.408 \\
\hline $\mathrm{NH}_{3}-\mathrm{N}(\mathrm{mg} / \mathrm{dL})$ & 18.1 & 19.1 & 20.1 & 17.8 & 0.365 & $<0.001$ & 0.865 & 0.024 \\
\hline \multicolumn{9}{|c|}{ Concentration (mmol/100 mmol) } \\
\hline Acetate & 62.6 & 62.2 & 62.2 & 62.8 & 0.002 & $<0.001$ & 0.798 & 0.158 \\
\hline Propionate & 22.6 & 23.4 & 23.3 & 22.5 & 0.002 & $<0.001$ & 0.795 & 0.012 \\
\hline Butyrate & 14.8 & 14.4 & 14.5 & 14.8 & 0.009 & $<0.001$ & 0.967 & 0.046 \\
\hline \multicolumn{9}{|l|}{ Production (mol) } \\
\hline Acetate & 6.45 & 6.69 & 6.78 & 7.14 & 0.008 & $<0.001$ & $<0.001$ & 0.653 \\
\hline Propionate & 2.39 & 2.54 & 2.58 & 2.61 & 0.052 & $<0.001$ & 0.036 & 0.457 \\
\hline Butyrate & 1.53 & 1.56 & 1.57 & 1.70 & 0.023 & $<0.001$ & 0.004 & 0.235 \\
\hline $\mathrm{SCFA}^{\mathrm{c}}$ & 10.9 & 11.4 & 11.5 & 12.0 & 0.151 & $<0.001$ & 0.001 & 0.829 \\
\hline $\mathrm{A}: \mathrm{P}^{\mathrm{d}}$ & 2.86 & 2.81 & 2.78 & 2.90 & 0.037 & 0.001 & 0.689 & 0.054 \\
\hline
\end{tabular}

a Dietary addition of $0,8,16$, and $24 \mathrm{~g} / \mathrm{cow}$ per day of exogenous fibrolytic enzymes.

b Variable were tested for time*treatment interaction but were not significant.

c Total short-chain fatty acids.

d Acetate to propionate ratio.

Total-tract digestion of nutrients was similar among the treatments, likewise reported in other studies (Peters et al., 2010; Knowlton et al., 2002). Therefore, these results suggest that digestion time has no influence from EFE supply, but rates are affected and showing a positive effect on DM intake (Beauchemin et al., 2003a,b). Conversely, several studies have shown increases of DM, NDF and ADF total tract digestion when supplying fibrolytic enzymes to lactating dairy cows (Bowman et al., 2002; Arriola et al., 2011). Several factors may influence responses to enzyme supplementation, including its preparation and amounts (Beauchemin et al., 2003a), supply method (Schingoethe et al., 1999; Kung et al., 2002), to which fraction of the diet it is added (Bowman et al., 2002), animal lactation stage (Knowlton et al., 2002), and limited knowledge of its action mechanism (Beauchemin and Holtshausen, 2010). It was expected that fiber intake growth would lead to a NDF digestibility decline, but our findings demonstrated lack of fiber digestibility problems and thus proving the effectiveness of EFE.

Studies have shown that whether fed TMR dairy cows sort rations against long particles and in favor of smaller ones (Leonardi and Armentano, 2003; DeVries et al., 2007). However, this behavior may bring problems once cows, while feeding smaller particle sizes, NDF intake is reduced because TMR larger particles contain higher amoutns of NDF if compared to the other fractions (Leonardi and Armentano, 2003). The current experiment demonstrated an increase of longer fiber intake when supplying EFE for cows, which must be related to an increased ruminating time and NDF intake of cows supplemented with EFE. Similarly, Krause et al. (2002) reported positive associations of intake of larger particle sizes and ruminating time. As well, Leonardi et al. (2005) observed a correlation between longer fibers and NDF intakes.

Adding EFE to feedstuffs may cause release of reducing sugars and partially degrade NDF and ADF (Krause et al., 1998). Even though fiber hydrolysis prior to ingestion could decrease both chewing and ruminating time, we observed longer durations for these processes, due to higher DM and NDF intakes provided by EFE supplement. Notwithstanding, Armentano and Pereira (1997) noted a negative correlation between chewing time and milk yield. Beauchemin et al. (2003b) observed that physically effective NDF of diets is positively correlated to chewing time, which could impair the efficiency of milk yield. Leonardi et al. (2005), studying the geometric of food particles, found that increasing sizes caused declines in milk yield and raises in time spent chewing, fueling the demand for dairy herd maintenance. Herein, intermediate doses ( $8 \mathrm{~g} / \mathrm{d}$ and $16 \mathrm{~g} / \mathrm{d}$ ) resulted in higher NDF intake and chewing time, which might have affected animal energy use. Additionally, nitrogen urinary excretion was exacerbated when the diet was supplemented with highest EFE dose. Likewise, Arndt et al. (2015) associated $\mathrm{N}$ retention depletions with increasing $\mathrm{N}$ excretion via the urine for animals receiveing diets with high amounts of degradable protein.

Cows used in this experiment were after the peak of lactation, when milk yield falls and animals gain weight over the time. After that, body architecture and physiological changes favor carcass deposition due to a decrease in peripheral tissue insulin resistance (observed during early lactation) leading to weight gain (Allen and Piantoni, 2014). Furthermore, studies have reported an increasing trend of milk yield in early lactating cows (Rode et al., 1999; Yang et al., 1999). Interestingly, although Beauchemin et al. (2000) observed no effects of EFE on milk production of mid-lactation cows, these authors described weight gain of animals. Given the above, we may infer that lactation stage interfere with animal response to EFE, as described by Knowlton et al. (2002). Besides of that, the effects of EFE supplementation seem to increase if ruminal endogenous capacity to degrade fiber is declined, which occurs during the early lactation (Knowlton et al., 2002). Elwakeel et al. (2007) found a quadratic effect on body weight gain of animals supplemented with increasing doses of EFE, among which, intermediate doses promoted the lowest gains. These authors suggested changes in distribution of nutrients were caused by enzyme supplementation, increasing carcass deposition by adding high doses of it.

Regarding ruminal parameters, EFE supplementation had a quadratic effect on ammonia N, which may partially explain the high $\mathrm{N}$ retention using intermediate doses of EFE. Similar results were found in cattle and sheep, due to a greater 
ruminal digestibility of diets supplemented with EFE compared to control diets (Hristov et al., 2000; Bhasker et al., 2013). In addition, acetate, propionate, and butyrate ruminal production linearly increased, which might have occurred because of improvements in ruminal enzyme activity and, consequently, greater availability of fermentable soluble carbohydrates (Hristov et al., 2000; Pinos-Rodriguez et al., 2002; Bhasker et al., 2013). Metabolites released from the cell-wall hydrolysis by the first colonizing microorganisms may stimulate secondary colonizers adherence to feed particles, increasing fermentation rates (Wang et al., 2001). Furthermore, ruminating time lasted longer with EFE supplementation ensuring greater access to feed particles for bacteria during fermentation, thus increasing total SCFA production. Apart from that, propionate production increased while butyrate decreased with added EFE, suggesting a shift in fermentative pathway regarding the synthesis of gluconeogenic precursors, indicating a diverse ruminal bacterial population compared to untreated diets (Giraldo et al., 2008).

\section{Conclusion}

Exogenous fibrolytic enzymes increased DM and NDF intake, increasing both chewing and ruminating time of cows. Although EFE supplementation increased the total production of SCFA in rumen, no alterations were observed for milk yield and composition of mid-lactating dairy cows.

\section{Conflict of interest}

The authors declare that there are no conflict of interest.

\section{Acknowledgments}

The authors acknowledge Dairy Cattle Research Laboratory of University of Sao Paulo, for providing the infrastructure and staff necessary for this study. Authors also acknowledge the Sao Paulo Research Foundation (FAPESP) for providing the scholarship of the first author (grant \#2014/13202-3).

\section{References}

AOAC, 2000. Official Methods of Analysis, 17th ed. Association of Official Analytical Chemists, Arlington, VA, USA.

Allen, M.S., Piantoni, P., 2014. Carbohydrate nutrition: managing energy intake and partitioning through lactation. Vet. Clin. North Am. Food Anim. Pract. 30, 577-597.

Armentano, L., Pereira, M., 1997. Measuring the effectiveness of fiber by animal response trials. J. Dairy Sci. 80, $1416-1425$.

Arndt, C., Powell, J.M., Aguerre, M.J., Wattiaux, M.A., 2015. Performance, digestion, nitrogen balance, and emission of manure ammonia, enteric methane, and carbon dioxide in lactating cows fed diets with varying alfalfa silage-to-corn silage ratios. J. Dairy Sci. 98, 418-430.

Arriola, K.G., Kim, S.C., Staples, C.R., Adesogan, A.T., 2011. Effect of fibrolytic enzyme application to low and high concentrate diets on the performance of lactating dairy cattle. J. Dairy Sci. 94, 832-841.

Beauchemin, K.A., Rode, L.M., Maekawa, M., Morgavi, D.P., Kampen, R., 2000. Evaluation of a non-starch polysaccharidase feed enzyme in dairy cow diets. J. Dairy Sci. 83, 543-553.

Beauchemin, K.A., Colombatto, D., Morgavi, D.P., Yang, W.Z., 2003a. Use of exogenous fibrolytic enzymes to improve feed utilization by ruminants. J. Anim. Sci. 81, E37-E47.

Beauchemin, K.A., Yang, W.Z., Rode, L.M., 2003b. Effects of particle size of alfalfa-based dairy cow diets on chewing activity, ruminal fermentation, and milk production. J. Dairy Sci. 86, 630-643.

Bhasker, T.V., Nagalakshmi, D., Rao, D.S., 2013. Development of appropriate fibrolytic enzyme combination for maize stover and its effect on rumen fermentation in sheep, asian austr. J. Anim. Sci. 26, 945-951.

Bowman, G.R., Beauchemin, K.A., Shelford, J.A., 2002. The proportion of the diet to which fibrolytic enzymes are added affects nutrient digestion by lactating dairy cows. J. Dairy Sci. 85, 3420-3429.

Broderick, G.A., Clayton, M.K., 1997. A statistical evaluation of animal and nutritional factors influencing concentrations of milk urea nitrogen. J. Dairy Sci. 80, 2964-2971.

Broderick, G.A., Kang, J.H., 1980. Automated simultaneous determination of ammonia and total amino acids in ruminal fluid in vitro media. J. Dairy Sci. 63 , 64-75.

Burns, J.C., 2008. ASAS centennial paper: utilization of pasture and forage by ruminants: historical perspective. J. Anim. Sci. 86, $3647-3663$.

Casali, A.O., Detmann, E., Valadares Filho, S.C., 2008. Influência do tempo de incubação e do tamanho de partículas sobre os teores de compostos indigestíveis em alimentos e fezes bovinas obtidos por procedimentos in situ. R. Bras. Zootec. 37, 335-342.

Chizzotti, M.L., Valadares, S.C., Valadares, R.F.D., Chizzotti, F.H.M., Tedeschi, L.O., 2008. Determination of creatinine excretion and evaluation of spot urine sampling in Holstein cattle. Livest. Prod. Sci. 113, 218-225.

DeVries, T.J., Beauchemin, K.A., von Keyserlingk, M.A.G., 2007. Dietary forage concentration affects the feed sorting behavior of lactating dairy cows. J. Dairy Sci. 90, 5572-5579.

Elwakeel, E.A., Titgemeyer, E.C., Johnson, B.J., Armendariz, C.K., Shirley, J.E., 2007. Fibrolytic enzymes to increase the nutritive value of dairy feedstuffs. J. Dairy Sci. 90, 5226-5236.

Giraldo, L.A., Ranilla, M.J., Tejido, M.L., Carro, M.D., 2008. Effects of exogenous fibrolytic enzymes on in vitro ruminal fermentation of substrates with different forage:concentrate ratios. Anim. Feed Sci. Technol. 141, 306-325.

Hall, M.B., Nennich, T.D., Doane, P.H., Brink, G.E., 2015. Total volatile fatty acid concentrations are unreliable estimators of treatments effects on ruminal fermentation in vivo. J. Dairy Sci. 98, 3988-3999.

Hall, M.B., 2000. Calculation of non-structural carbohydrate content of feeds that contain non-protein nitrogen. University of Florida, Gainesville, p. A-25 (Bulletin, 339).

Hristov, A.N., McAllister, T.A., Cheng, K.J., 2000. Intraruminal supplementation with increasing levels of exogenous polysaccharide-degrading eznymes: effects on nutrient digestion in cattle fed barley grain diets. J. Anim. Sci. 78, 477-487.

Kenward, M.G., Roger, J.H., 1997. Small sample inference for fixed effects from restricted maximum likelihood. Biometrics 53, 983-997.

Knowlton, K.F., McKinney, J.M., Cobb, C., 2002. Effect of a direct-fed fibrolytic enzyme formulation on nutrient intake, partitioning, and excretion in early and late lactation Holstein cows. J. Dairy Sci. 85, 3328-3335. 
Kononoff, P.J., Buckmaster, D.R., 2003. Modification of the Penn State Particle Separator and the effects of moisture on its measurements. J. Dairy Sci. 86, $1858-1863$.

Krause, M., Beauchemin, K.A., Rode, L.M., Farr, B.I., Norgaard, P., 1998. Fibrolytic enzyme treatment of barley grain and source of forage in high grain diets fed to growing cattle. J. Anim. Sci. 96, 1010-1015.

Krause, K.M., Combs, D.K., Beauchemin, A., 2002. Effects of forage particle size and grain fermentability in midlactation cows. II. Ruminal pH and chewing activity. J. Dairy Sci. 85, 1947-1957.

Kung Jr., L., Cohen, M.A., Rode, L.M., Treacher, R.J., 2002. The effect of fibrolytic enzymes sprayed onto forages and fed in a total mixed ratio to lactating dairy cows. J. Dairy Sci. 85, 2396-2402.

Leonardi, C., Shinners, K.J., Armentano, L.E., 2005. Effect of different dietary geometric mean particle length and particle size distribution of oat silage on feeding behavior and productive performance of dairy cattle. J. Dairy Sci. 88, 698-710.

Meale, S.J., Beauchemin, K.A., Hristov, A.N., Chaves, A.V., McAllister, T.A., 2014. Board-invited review: opportunities and challenges in using exogenous enzymes to improve ruminant production. J. Anim. Sci. 92, 427-442.

Mertens, D.R., Huhtanen, P., 2007. Grass forages: dynamics of digestion in the rumen. In: New York State ruminan health-nutrition conference. Proceedings.. Syracuse, 20.

Morgavi, D.P., Beauchemin, K.A., Nsereko, V.L., Rode, L.M., Iwaasa, A.D., Yang, W.Z., 2000. Synergy between ruminal fibrolytic enzymes and enzymes from Trichoderma longibrachiatum. J. Dairy Sci. 83, 1310-1321.

NRC, 2001. National Research Council. Nutrient Requirements of Dairy Cattle, 7. ed. National Academic Press, Washington, D.C.

Oba, M., Allen, M.S., 2003. Effects of corn grain conservation method on ruminal digestion kinetics for lactating dairy cows at two dietary starch concentrations. J. Dairy Sci. 86, 184-194.

Peters, A., Lebzien, P., Meyer, U., Borchert, U., Bulang, M., Flachowsky, G., 2010. Effect of exogenous fibrolytic enzymes on ruminal fermentation and nutrient digestion in dairy cows. Arch. Anim. Nutr. 64, 221-237.

Pinos-Rodriguez, J.M., González, S.S., Mendoza, G.D., Bárcena, R., Cobos, M.A., Hernández, A., Ortega, M.E., 2002. Effects of exogenous fibrolytic enzyme on ruminal fermentation and digestibility of alfalfa and ryegrass hay fed to lambs. J. Anim. Sci. 80, 3016-3020.

Reddish, M.A., Kung Jr., L., 2007. The effect of feeding a dry enzyme mixture with fibrolytic activity on the performance of lactating cows and digestibility of a diet for sheep. J. Dairy Sci. 90, 4724-4729.

Rode, L.M., Yang, W.Z., Beauchemin, K.A., 1999. Fibrolytic enzyme supplements for dairy cows in early lactation. J. Dairy Sci. 82, $2121-2126$.

Schingoethe, D.J., Stegeman, G.A., Treacher, R.J., 1999. Response of lactating dairy cows to a cellulase and xylanase enzyme mixture applied to forages at the time of feeding. J. Dairy Sci. 82, 996-1003.

Silveira, C., Oba, M., Yang, W.Z., Beauchmin, K.A., 2007. Selection of barley grain affects ruminal fermentation, starch digestibility, and productivity of lactating dairy cows. J. Dairy Sci. 90, 2860-2869.

Sklan, D.R., Ashkenazi, R., Braun, A., Devorin, A., Tabori, K., 1992. Fatty acids, calcium soaps of fatty acids, and cotton seeds fed to high yielding cows. J. Dairy Sci. 75, 2463-2472.

Valadares Filho, S.C., Machado, P.A.S., Chizzotti, M.L., Amaral, H.F., Maglhães, K.A., Rocha Junior, V.R., Capelle, E.R., 2016. CQBAL 3.0. Tabelas Brasileiras de Composição de Alimentos para Bovinos. www.ufv.br/cqbal (accessed 27.01.16.).

Van Soest, P.J., Mason, V.C., 1991. The influence of Maillard reaction upon the nutritive value of fibrous feeds. Anim. Feed Sci. Technol. 32 , 45-53.

Varga, G.A., Kolver, E.S., 1997. Microbial and animal limitations to fiber digestion and utilization. J. Nutr. 127, 819-823.

Vicini, J.L., Bateman, H.G., Bhat, M.K., Clark, J.H., Erdman, R.A., Phipps, R.H., Van Amburgh, M.E., Hartnell, G.F., Hintz, R.L., Hard, D.L., 2003. Effect of feeding supplemental fibrolytic enzymes or soluble sugars with malic acid on milk production. J. Dairy Sci. 86, 576-585.

Wang, Y., Mcallister, T.A., Rode, L.M., Beauchemin, K.A., Morgavi, D.P., Nsereko, V.L., Iwaasa, A.D., Yang, W., 2001. Effects of an exogenous enzyme preparation on microbial protein synthesis, enzyme activity and attachment to feed in the Rumen simulation technique (Rusitec). Br. J. Nutr. 85, 325-332.

Weiss, W.P., Conrad, H.R., Pierre, N.R.S., 1992. A theoretically-based model for predicting total digestible nutrient values of forages and concentrates. Anim. Feed Sci. Technol. 39, 95-110.

Welch, J.G., 1982. Rumination, particle size and passage from the rumen. J. Anim. Sci. 54, 885-894.

Yang, W.Z., Beauchemin, K.A., Rode, L.M., 1999. Effects of an enzyme feed additive on extent of digestion and milk production of lactating dairy cows. J. Dairy Sci. 82, 391-403.

Yang, W.Z., Beauchemin, K.A., Rode, L.M., 2000. A comparison of methods of adding fibrolytic enzymes to lactating cow diets. J. Dairy Sci. 83, $2512-2520$. 